University of Louisville

ThinkIR: The University of Louisville's Institutional Repository

Faculty Scholarship

7-2012

\title{
The role of case complexity in judicial decision making.
}

Laura P. Moyer

University of Louisville, laura.moyer@louisville.edu

Follow this and additional works at: https://ir.library.louisville.edu/faculty

Part of the American Politics Commons, Judges Commons, and the Law and Politics Commons

\section{Original Publication Information}

This is the peer reviewed version of the following article:

Moyer, Laura P. "The Role of Case Complexity in Judicial Decision Making." 2012. Law and Policy 34(3):

291-312.

which has been published in final form at http://dx.doi.org/10.1111/j.1467-9930.2012.00362.x. This article may be used for non-commercial purposes in accordance with Wiley Terms and Conditions for Self-Archiving.

This Article is brought to you for free and open access by ThinkIR: The University of Louisville's Institutional Repository. It has been accepted for inclusion in Faculty Scholarship by an authorized administrator of ThinkIR: The University of Louisville's Institutional Repository. For more information, please contact thinkir@louisville.edu. 
The Role of Case Complexity in Judicial Decision Making

\author{
Laura P. Moyer \\ Louisiana State University \\ $\underline{\text { lmoyer@1su.edu }}$ \\ Version: 28 November2011
}




\section{The Role of Case Complexity in Judicial Decision Making}

The literature on ideology and decision making offers conflicting expectations about how judges' ideology should affect their votes in cases that raise many legal issues. Using cases from the U.S. Courts of Appeals, I examine the strength of ideology as a predictor of sincere voting in single and multi-issue cases and test whether the same effect for ideology can be seen for liberal and conservative judges. For all judges, ideology yields a larger effect as the number of issues increases; however, conservative judges are much more likely than liberal judges to cast sincere votes at all levels of complexity. 


\section{The Role of Case Complexity in Judicial Decision Making}

A wide range of literature in political science emphasizes the centrality of ideology in explaining political elites' behavior. Studies of both Congress and the U.S. Supreme Court have shown the ways that institutional constraints and norms can shape the opportunities for ideologically driven behavior, at both the agenda-setting stage (e.g., Caldeira, Wright, and Zorn 1999; Krehbiel and Rivers 1998) as well as the final decision stage (e.g., Segal and Spaeth 1993; Poole and Rosenthal 1991). In studies of legislative behavior, ideology is viewed as a conscious, explicit motivation for individual behavior (Krehbiel 1993, 1998), though not necessarily the only possible motivating factor (Binder, Lawrence, and Maltzman 1999; Cox and McCubbins 1993; Kingdon 1973). This way of understanding ideology as an acceptable basis for political decision making reflects the values underlying elective office; namely, that because the electorate chooses legislators on the basis of their ideological positions on policy matters, it is then desirable for public officials to act in a manner consistent with their ideological position. ${ }^{\mathrm{i}}$

However, in the context of judicial institutions (and particularly the federal judiciary), there are strong norms opposing a conscious, explicit reliance on ideology as an appropriate basis for judicial decision making. Like the norms about acceptable legislative behavior, the norms about judicial actors also reflect the values underlying the selection mechanism used, which emphasizes independence and insulation from public opinion. In this paper, I move away from the debate over whether ideology should matter in judicial decision making and connect to a more recent segment of research that acknowledges two points. First, due to their legal education and professional socialization, legal decision makers believe that law matters, and this has consequences for how judges behave (Braman 2006; Baum 1997), particularly in institutional contexts other than the U.S. Supreme Court. Second, this emerging body of 
research acknowledges that it is vital to begin exploring the process by which ideological frames operate to influence legal decision making (i.e., asking, how ideology affects legal decision making, rather than, does ideology affect legal decision making).

Competing perspectives exist about how ideology functions in judicial decision making. Braman and Nelson (2007) characterize these approaches as either "top down" or "bottom up." In the "top down" model (e.g., Segal and Spaeth 1993), outcome decisions are made first and then affect which legal explanations are offered as a rationalization. In the "bottom up" model (Baum 1999; Rowland and Carp 1996), judges' attitudes behave like “information filters [that affect] ... micro-decisions that occur in the process of legal reasoning" (Braman and Nelson 2007, 942).

I build on this literature by exploring the cognitive function that ideology plays in "noisy" decision-making environments. Specially, I examine the role of ideology for appellate judges in "complex" cases that raise many legal issues, compared to cases that present fewer dimensions. The paper proceeds in the following manner. First, I discuss the major existing theoretical perspectives on the function of ideology in judicial decision making, highlighting differences in how ideology is defined in each. Next, I discuss how ideological frames might be used, unconsciously, to simplify judicial decision making under these conditions, and suggest several hypotheses. Testing these on a sample of published decisions in the U.S. Courts of Appeals from 1982 to 2002 , I find evidence that increased complexity is not associated with ideologically "sincere" voting for liberals, but that it is for conservative judges. I conclude by discussing the implications of my results for the "law versus ideology" debate about judging. 


\section{Ideology and Judicial Decision Making}

\section{Prominent models}

The function of ideology is viewed quite differently by the prominent political science models of judging. In the attitudinal model articulated by Segal and Spaeth (1993, 2002), ideology is the central explanatory factor for judicial decision making on the U.S. Supreme Court. Under this account, judges make decisions based on their ideology: "the Supreme Court decides disputes in light of the facts of the case vis-à-vis the ideological attitudes and values of the justices. Simply put, Rehnquist votes the way he does because he is extremely conservative; Marshall voted the way he did because he was extremely liberal” (Segal and Spaeth 2002, 86). Attitudinalist scholars use the word "ideology" interchangeably with several other terms: "policy preferences" (Rohde and Spaeth 1976), "policy goals” (Klein 2002; Baum 1997), “ideal points” (Schubert 1965, 1974), “attitudes” (Segal and Spaeth 1993, 2002; Spaeth and Peterson 1971), and "values" (Pritchett 1948). As described by Harold Spaeth (1972), the way ideology enters into the judicial decision-making process is a multi-step process. First, a judge must hold an attitude, defined as "an interrelated set of beliefs about an object or situation" (65). Judges will have attitudes about the parties involved in the case, as well as about the central legal issue in the case (Segal and Spaeth 2002). When these attitudes interact, they will influence a judge's behavior. ${ }^{\text {ii }}$ The attitudinal model implies that ideology serves as a simplifying mechanism in decision making: when judges possess attitudes about the parties and the legal issue in the case, the range of possible outcomes is constrained. Characterizations of the attitudinal model sometimes assume that this is a conscious process - what Gillman (2001) refers to as "low politics"- though Segal and Spaeth appear to be agnostic on whether judges are fully aware of 
this tendency (Baum 2009), focusing less on how this mechanism works than on whether the evidence is consistent with decisions based on policy preferences. ${ }^{\text {ii }}$

In contrast, empirical work that employs the "legal model" de-emphasizes the role of ideology in decision making, instead focusing on legal variables, such as precedent (Kritzer and Richards 2003; Richards and Kritzer 2002), statutes (Cook 1977), doctrinal cues (George and Epstein 1992), and fact patterns (Segal 1984). ${ }^{\text {iv }}$ Another branch of scholarship classified under the rubric of the "legal model" comes from legal professionals and law school faculty and is typically (though not always) distinct from empirical scholarship in taking a strong normative position that judges can and should avoid relying on ideology in any way in their decisions. A common criticism of such work is that it does not yield testable propositions (Cross 1997; Smith 1994; Segal and Spaeth 1993).

Finally, strategic models argue that judges possess multiple goals, one of which is to achieve their preferred policy outcome. Under the strategic model, ideology is said to matter within constraints, but perhaps more importantly, it posits a conscious recognition of attitudes and reliance on them in decision making. For instance, Epstein and Knight (1998) refer to judges as "policy seekers" and note that individual judges have been quoted saying that they think they can influence public policy.

In two of these three major approaches, then, ideology plays a prominent role in explaining judicial decisions. However, the specific causal mechanism by which ideology works to affect judicial decisions remains poorly understood. In the section that follows, I discuss what we know about the role of ideology in cognition and how that knowledge might strengthen our accounts of judicial decision making. 


\section{Ideology and Cognition}

Research in political psychology has generally characterized ideology as a coherent organizing framework for understanding the world (Converse 1964) that, at least in part, reflects individuals' psychological needs (Jost et al. 2003). ${ }^{\mathrm{V}}$ Several insights from this literature have immediate relevance for our inquiry into the bases of judicial decision making. First, one common perspective on ideology's role in cognition is that ideology can serve as a heuristic device, providing a cognitive "shortcut" when time and informational resources are scarce. Under this view, ideology's role in decision making is likely to go unnoticed by the decision maker - that is, the decision maker unconsciously relies upon his or her own ideology as a guide. Related to this perspective is research that finds an effect for ideology in evaluating the credibility of sources; for example, conservative individuals are more likely to accept information from a conservative source as reliable than they would if they associated the information as coming from a liberal source, and vice versa (Bailey, Kamoie, and Maltzman 2005; Lupia 2002).

Additionally, an individual's ideological position may be associated with a particular cognitive style in terms of the differentiation between and integration of concepts (Tetlock 1983). A robust debate persists between scholars who argue that cognitive simplicity is associated primarily with conservatism (Sidanius 1985, 1988; Tetlock 1983, 1984) and those who argue for a more symmetrical relationship between ideological extremity and cognitive simplicity (Ray 1973; Rokeach 1960; Shils 1954). However, more recent work has tended to find more support consistent with the "rigidity of the right" hypothesis (Altemeyer 1998; but see Gruenfeld 1995). Overall, what unites this body of literature is the premise that ideology is an 
important, and perhaps unavoidable, factor in influencing the content and manner of decision making.

In contrast, some legal scholars have argued that that judges' professional training "inoculates" them from the cognitive phenomena observed by psychologists in studies of nonjudges' decision making (Schauer 2007; but see Spellman 2007). This is no doubt due to the strong norm in legal education against relying upon ideology as a basis for legal decisions. However, research using law students and magistrate judges as experimental subjects suggests that neither law school training nor practicing the law may be enough to overcome common cognitive errors, or to make ideology entirely irrelevant (Braman and Nelson 2007; Guthrie, Rachlinski, and Wistrich 2001). On the other hand, Braman's 2006 experimental study on ideology and the separability of merits and threshold issues concluded that motivated reasoning, by itself, is insufficient as an explanation of legal decision making; law and legal norms appear to have some ability to constrain decision makers from acting solely on their ideological attitudes. ${ }^{\mathrm{vi}}$

Of course, the function of ideology in decision making differs depending on the institutional context. Zorn and Bowie (2010) show that judicial ideology plays an increasingly larger role in decisional outcomes at each level in the federal judicial hierarchy. Compared to the U.S. Supreme Court, ideology plays a less prominent role in the U.S. Courts of Appeals, for several reasons. First, as an intermediate court that must honor litigants' right to one appeal, the Courts of Appeals are sent more "cut-and-dried" cases to decide, which require only straightforward applications of existing law and often result in unanimous rulings. Second, ideology may be less relevant for circuit judges because, unlike the Supreme Court's Rule of Four for granting certiorari, circuit judges do not select the cases they hear. Substantial 
empirical support has demonstrated that Supreme Court justices' votes at the certiorari stage are consistent with ideological preferences (e.g., Boucher and Segal 1995), but the practice of random assignment in the Courts of Appeals makes it impossible for a circuit judge to "cherry pick" a case based on ideological grounds. Finally, because of strong institutional norms in the Courts of Appeals favoring consensus and requiring majority rule, ${ }^{\text {vii }}$ the ideology of the panel's median judge is especially important in influencing the tenor and ideological direction of the panel's majority opinion (Kastellac 2007; Hettinger, Lindquist, and Martinek 2006; Tiller and Cross 1999). However, recent work on the Courts of Appeals has also pointed to systematic differences between Democratic and Republican judicial appointees in the degree to which their ideological preferences are constrained by statutory language (Randazzo, Waterman, and Fine 2006). Judges appointed by Democratic presidents are less likely than their Republican colleagues to cast sincere votes in criminal cases, while Republican appointees are less likely to vote sincerely in discrimination cases.

Institutional context is also important in terms of understanding the coping strategies and heuristics used by decision makers. By three measures, it is abundantly clear that circuit court judges have very full plates. ${ }^{\text {viii }}$ On average, each year from 1983 to 2002, the Courts of Appeals averaged 4,092 filings, 2,071 cases terminated on their merits, and 26 merits cases per judge (Lindquist 2007). One appellate judge observed, “Caseload pressures greatly reduce one's sense of satisfaction with the job. I feel dirty at the end of the day, having made many decisions without time for proper reflection and analysis" (Robel 1990). Another lamented: "It’s huge. It's absolutely huge. And it does affect the way you work. Because when I was working on 1012 cases a month, it was far different than working on 30-40 cases. You have to give priority to certain cases; you're always behind.' ${ }^{\text {'ix }}$ Indeed, psychological research on group decision making 
suggests that stress can cause more simplified, heuristic-based decision making (Karau and Kelly 1992).

In the empirical scholarship focusing specifically on the U.S. Courts of Appeals, the relationship between case complexity, ideology, and judicial behavior has not been directly addressed. Rather, when complexity has been considered, it has been as a control variable. For example, Hettinger, Lindquist, and Martinek (2006) use two measures as proxies for complexity in their study of dissensus on appellate panels: the presence of a cross appeal and the number of headnotes coded in the Songer (2002) database. ${ }^{\mathrm{x}}$ They find that the number of legal issues, as indicated by the latter measure, is positively related to the likelihood of a concurrence, compared to joining the majority opinion, but is not related to the likelihood of a dissent. Other work (Lindquist, Martinek, and Hettinger 2007) finds that case complexity (as measured by a factor analysis of legal issues and opinion length) is a significant predictor of decisions to affirm in part and reverse in part ("mixed" outcomes). Taken together, these results suggest that as cases present more dimensions, judges are more likely to respond with fewer clear-cut decisions (i.e., separate opinions and split decisions).

While, overall, the literature on ideology and cognition does not provide a clear set of expectations about the effects of judicial ideology in complex cases, it is possible to draw a few general conclusions from the extent research. First, context is important, particularly in terms of decision making under stressful conditions. It is reasonable to assume that, given the heavy caseloads faced by appellate panels, unconscious reliance on heuristics is probably a common response to that decision environment. Second, ideology operates differently for individuals at different points in the ideological spectrum. This can be seen both in the political psychology literature and in work specifically examining federal appellate judges (Randazzo, Waterman, and 
Fine 2006). Building on these insights, in the section that follows, I lay out several hypotheses to test the competing contentions suggested by the literature.

\section{Theoretical Expectations}

The central assumption underlying this inquiry is that we should not expect ideology to have a uniform effect across all judges or all cases. If we imagine that ideology functions like a filter, it should simplify the decision making process by guiding judges as they prioritize different pieces of information. As more and more pieces of information flow into that filter, two responses are possible. Because of the stress associated with greater levels of complexity, ideology could become an even more influential heuristic, triggering more ideologically consistent voting as response to uncertainty (Karau and Kelly 1992). Alternatively, as complexity rises, it is possible that too many pieces of information would overwhelm an ideological framework, rendering it less meaningful as a filter and producing less ideologically consistent voting behavior. Each of these competing explanations is represented in the two hypotheses below.

Hypothesis 1: In cases with multiple issues, ideology will exert a stronger effect on a judge's vote than in cases with a single issue.

Hypothesis 2: In cases with multiple issues, ideology will exert a weaker effect on a judge's vote than in cases with a single issue.

In addition, the political psychology literature gives us reason to question whether ideology performs an equivalent function for ideologically extreme judges (both liberal and conservative) as well as those who are moderate. Past research on political elites offers mixed conclusions. In early studies examining U.S. senators and Supreme Court justices, Tetlock (1983) and Tetlock et al. (1985) found that liberal and moderate political elites exhibited more 
integrative complexity in their written and spoken rhetoric than conservatives. However, a more recent examination of the Supreme Court (Gruenfeld 1995) found that this difference between liberals and conservatives was an artifact of majority opinion status, not purely ideology. Finally, one recent study of the Courts of Appeals found ideological differences in which substantive areas of statutory law constrain judges, again suggesting that the function of ideology may differ depending on one's ideological position (Randazzo, Waterman, and Fine 2006). The same study also found that ideological extremity was only associated with sincere voting by Republican appointees, but not Democratic appointees.

To further examine whether ideology mediates the relationship between complexity and sincere voting, I also introduce competing hypotheses that test whether any conditional relationship is symmetrical or asymmetrical.

Hypothesis 3: In cases with multiple issues, judges with strong conservative preferences will be more likely to cast sincere votes than judges with strong liberal preferences.

Hypothesis 4: In cases with multiple issues, judges with more extreme ideological positions will be more likely to cast sincere votes than moderate judges will in such cases.

\section{Data and Methods}

The data used for these analyses are derived from the Multi-User Database on the U.S. Courts of Appeals, transformed so that a judge-vote was the unit of analysis (Songer 1997; Kuersten and Haire 2006) for the eleven numbered circuits for the years 1982 to 2002. After excluding cases in which no legal issues were coded, this yielded a total of 11,392 judge-votes for analysis, all of which came from three-judge panels.

To untangle the relationship between complexity and ideological voting, the dependent variable in the analysis predicts the likelihood of a judge casting a "sincere" vote. To ascertain 
what constitutes an ideologically "sincere" vote, the ideological direction of each vote must first be determined. The U.S. Courts of Appeals database contains this information, labeling each vote as "liberal," "conservative," "mixed," or "could not be classified." Ideological directionality is determined relative to each issue area; for example, in criminal cases, a vote in favor of the government is coded as a conservative outcome, while in economic regulation cases, a vote for the government is coded as a liberal outcome. (More detailed information about coding of each issue area can be found in the database codebook, available at http://www.cas.sc.edu/poli/juri/appct.htm). "Mixed" outcomes that supported both parties or that could not be clearly classified in ideological terms were omitted from this analysis. ${ }^{\mathrm{xi}}$

Next, following previous research that has uncovered significant differences between Democratic and Republican appointees, the dependent variable is coded as a " 1 " (sincere) if a Republican appointee cast a conservative vote or a Democratic appointee cast a liberal vote. It is coded as a "0" (not sincere) if a Republican appointee cast a liberal vote, or a Democratic appointee cast a conservative vote. Finally, because of the dichotomous nature of the dependent variable, I estimate a logistic regression model with robust standard errors. ${ }^{\text {xi }}$

\section{Independent Variables}

In order to evaluate the relationship between complexity and ideologically sincere voting, it is important to control for judicial ideology. A continuous variable is superior to a dichotomous approach because it allows for a more precise and nuanced measure as well as allowing distinctions to be made between ideological extremes and moderates (Epstein, Martin, Segal, and Westerland 2007). For these reasons, I use the Giles, Hettinger, and Peppers (2001) ideology scores, which range from -1 (most liberal) to +1 (most conservative) and reflect the preferences of the appointing president or the home state senator(s) when senatorial courtesy is 
present. However, I adjust this measure somewhat to reflect bargaining between the president and the home state senator by averaging the two NOMINATE scores when senatorial courtesy is present. The values for Judge Ideology in this sample range from -.689 to .6, with a median value of .25. To further distinguish among judges ideologically in terms of being "moderate" or “extreme," I then created a dummy variable called Extreme that is equal to 1 if the judge was at the $75^{\text {th }}$ percentile or greater among other appointees of the same party, and 0 if they fell below the $75^{\text {th }}$ percentile. ${ }^{\text {xii }}$ To account for the possibility that ideologically sincere voting may be driven by whether the judge is a part of the majority coalition on the circuit, Majority is equal to 1 if the judge was of the same party as 51 percent or more of the circuit, zero if the circuit was evenly balanced (50-50), and -1 if the judge was a part of the minority party on the circuit.

Both practitioners and academics have developed measures of case complexity, albeit for different purposes. Court management efforts to measure case complexity have generally been geared toward improving efficiency in the disposition of cases, though such efforts are not uniform across all circuits (McKenna, Hooper, and Clark 2000). In contrast, political scientists and empirical legal scholars have generally included various measures of case complexity as control variables in their analyses, rather than as the central explanatory variable (e.g., Lindquist, Martinek, and Hettinger 2007; Hettinger, Lindquist, and Martinek 2006).

For the purposes of the present inquiry, I focus on the aspect of complexity that relates to the number of legal concepts involved in a case (see Johnson 1987). This variable is a count of the number of legal concepts identified in an opinion, taken from the Multi-User Database on the U.S. Courts of Appeals (Kuersten and Haire 2006; Songer 1997). Under each area of law (criminal, civil disputes between private entities, civil disputes between private entities and government, and administrative agency appeals), coders identified whether specific legal issues 
were present in the opinion or not. (The legal concepts coded for each area of law appear in the appendix.) For this analysis, concepts mentioned in the opinion were coded as 1 and zero if otherwise, then summed. ${ }^{\text {xiv }}$ Legal Complexity ranges from 1 to 13 issues, with a median of 2 issues $($ standard deviation $=1.29)$. To adjust for the skewed distribution of this variable, $\mathrm{I}$ transformed the raw number by taking its square root, which changes the range to run from 1 to 3.6. I also included a dummy variable to control for the presence of a cross appeal, which by definition, raises multiple issues, since both parties are appealing separate issues from the district court's decision (Hettinger, Lindquist, and Martinek 2006). Cross Appeal and Legal Complexity tap into different aspects of multiple issues, as evidence by their low correlation $(r=.09)$.

To gauge whether the effect of ideology on sincere voting is conditioned by complexity, I included two interaction terms. The first, Ideology*Legal Complexity, examines whether differences exist between liberal and conservative judges in how case complexity conditions their vote. The second multiplicative term, Extreme*Legal Complexity, tests whether differences exist between ideological moderates and extremes with respect to this conditional relationship. Additionally, I include several control variables. I control for the participation of the U.S. government, which retains a strong advantage in litigation (Songer, Sheehan, and Haire 1999). The variable U.S. government takes the value of -1 if the United States is a party and takes the position contrary to the judge's preferences, zero if the United States is not a party in the case, and +1 if the United States is involved and takes a position that is consistent with a judge's "sincere" position. To account for the court's overwhelming tendency to affirm lower courts' decisions, Lower Court is equal to one if the district court ruled in the direction consistent with the judge's preferences, and equal to zero if it ruled in the opposing direction. Finally, because a judge's propensity to cast a "sincere" vote may be a function of the ideological 
positions of his or her colleagues on the panel, I created a variable that is the absolute value of the distance between the majority opinion author and the panel median (Panel Distance).

[Table 1 about here]

\section{Findings}

Table 1 displays the results from the logit models. ${ }^{\mathrm{xv}}$ In the first column of results (Model 1), the model presented does not include any interaction terms. Here, we can get a sense of how ideology and complexity affect sincere voting separately, before examining whether they have a conditional effect. We can see that Legal Complexity by itself does not exert a statistically significant effect on sincere voting, although the coefficient is positively signed. Conservative judges are significantly more likely than their liberal colleagues to cast ideologically sincere votes, and counter to expectations, moderate judges have a higher probability of voting sincerely than more ideologically extreme judges. Looking at the other control variables, when the position of the lower court is consistent with a judge's preferences, or when the U.S. government takes a position consistent with a judge's preferences, it is more likely that the judge will cast an ideologically sincere vote. In particular, the Lower Court variable exerts a very large effect; with all other variables held at their median values, a one-unit change in Lower Court (from zero to one) causes the likelihood of a sincere vote to jump from .51 to .95 . This finding reflects the tendency of appellate judges to affirm lower court decisions, but also emphasizes, consistent with the attitudinal model, that it is easier to agree with the district court when that outcome is consistent with one's ideological preferences. The Majority variable is positive and significant, with a relatively large effect as well. When all other variables are held at their median or modal values, moving from being in the minority coalition to the majority coalition within the circuit increases the probability of a sincere vote from .36 to .51 . 
[Figure 1 about here]

In the second column of Table 1 , the model is estimated with an interaction term between Ideology and Legal Complexity, which allows us to evaluate the first three hypotheses. When the model is estimated including this multiplicative term, the results show that Ideology*Legal Complexity is not statistically significant. However, because the statistical and substantive significance for interaction terms are not always accurately reflected by the coefficients and standard errors reported in model output, it is important to calculate the marginal effects and standard errors for scenarios of interest (Brambor, Clark, and Golder 2006; Norton, Wang, and Ai 2004). Setting all other variables at their median values and the lower court variable at zero, I calculated the marginal effects for both moderates and extremes as the Legal Complexity variable increased from its minimum (1) to its maximum (3.6) for judges at the $25^{\text {th }}$ and $75^{\text {th }}$ percentile of ideology. Figure 1 shows the conditional effect of legal complexity on ideology for both liberal and conservative judges. Consistent with Hypothesis 1 , the probability of a sincere vote increases somewhat for all judges as the number of issues in a case rises. This allows us to reject Hypothesis 2 (which predicted the opposite result). Additionally, Figure 1 clearly shows that conservative judges are significantly more likely to cast a sincere vote than liberal judges, supporting Hypothesis 3. Over the range of legal issues, the probability for conservative judges increases from .62 to .65 , while the probability for liberal judges increases from .35 to .39 . At the highest levels of complexity (3.4 and higher), however, there are no meaningful differences between conservative and liberal judges. ${ }^{\text {xvi }}$

[Figure 2 about here]

In the third column of results in Table 1 (Model 3), an interaction term between Extreme and Legal Complexity allows us to test Hypothesis 4; namely, that ideologically extreme judges 
will be more likely to cast sincere votes in conditions of higher complexity than moderate judges. The results for the control variables in this model are identical to those in Model 1, and the coefficient on the interaction term Extreme ${ }^{*}$ Complexity fails to reach conventional levels of statistical significance. However, when the marginal effects and standard errors are calculated (with all variables held at their median values) and graphed, moderates are actually more likely than ideological extremes to cast sincere votes when a case has low to medium levels of complexity. (At higher levels of complexity, the confidence intervals overlap, signifying that the two groups are no longer statistically distinguishable from one another.) Over the range of Legal Complexity, however, we see no evidence for either moderates or extremes that complexity increases (or decreases) the likelihood of sincere voting, as the relationship is flat. Thus, we can conclude that Hypothesis 4 is not supported, since ideological extremity is not positively related to sincere voting.

\section{[Table 2 about here]}

Finally, we examine the possibility that the findings are an artifact of the type of case (civil or criminal) being heard. Since a large portion of the appellate docket is made up by criminal cases, which are typically affirmed at a higher rate than other types of cases (Lindquist 2007), one possible explanation for the findings above is that conservative judges' greater propensity to vote sincerely is being driven by case type. Table 2 shows the results from additional analyses that examine civil and criminal cases separately. ${ }^{\text {xvii }}$ Models 4 and 5 are estimated including the interaction between Ideology and Legal Complexity and between Extreme and Legal Complexity to test for conditional effects within these subsamples. ${ }^{\text {xvii }}$ In these models, Extreme*Legal Complexity is the only statistically significant conditional relationship, and it only is significant in civil cases in a relatively narrow range. Moderates are 
more likely than ideological extremists to cast sincere votes in civil cases and increasingly more so as Legal Complexity increases from its minimum to its $90^{\text {th }}$ percentile value. (Graphs for other, non-significant interaction terms omitted because of space). Consequently, it does not appear that the results for the conditional effect of complexity on ideology that we saw above are being driven by outcomes in criminal cases.

[Figure 3 about here]

In sum, we can draw several conclusions from these findings. First, as shown in Figure 1, we find evidence that ideology has a stronger influence as a case contains more issues, though the effect is not overwhelming. This suggests that ideology can be a somewhat effective filter in simplifying the decision environment as it becomes more "crowded" with information.

In addition, Figure 1 shows that differences exist between liberal and conservative judges with respect to the general propensity for casting ideologically sincere votes, and that these differences are not a function of ideological extremism. Specifically, conservative judges are more likely to cast sincere votes across the board and are increasingly likely to do so as a case becomes more complex. This provides some tentative support for the work of some political psychologists (see Jost et al. 2003a for an overview), who have argued that conservatism is composed of a number of underlying traits (e.g., intolerance of ambiguity and the need for order, structure, and closure) that are associated with eliminating nuance and simplifying complex phenomena. Obviously, the normative implications of these studies are quite controversial (see Greenberg and Jonas 2003; Jost et al. 2003b), but given the results shown here, we can at least say that conservatism appears to help conservative judges make ideologically consistent decisions in the midst of "noisy" decision environments. Liberal judges, too, rely more on their ideology as cases become more complex, but their ideological position does not yield nearly as 
large an effect, predicting a sincere vote only about one-third of the time. This difference between liberal and conservative judges cannot be explained by the attitudinal model alone, since it suggests that ideology acts as a stronger filter for conservative judges than it does for liberal judges.

\section{Discussion}

Prior research on the U.S. Courts of Appeals has demonstrated that, rather than pitting law against ideology as an explanatory mechanism, elements of both factors play an important part in explaining judicial decision making (Klein 2002; Segal, Songer, and Cameron 1995). Much of the time, circuit court judges come to the same conclusion, liberal and conservative alike, perhaps because the law is often easily applied to many appeals - and also because the decision environment promotes consensual decision-making norms. On the other hand, the evidence shows that measures of judge ideology, both at the individual and panel level, are consistently significant predictors of voting behavior.

The findings described herein have important implications for the "attitudes versus law" debate among judicial scholars. While much of the work in this subfield has focused on modeling law as a uniform constraint, this study considers how the law matters from an information processing perspective. I argue that it is vital to consider the complexity of cases when making arguments about the relative power of law or ideology as explanatory mechanisms. The results show that the effect of ideology as a "filter" grows increasingly stronger as case complexity increases, for all judges. However, conservative ideology is associated with a higher tendency to cast sincere votes at all levels of complexity, compared to liberal ideology. The lack of equivalence between the two groups is notable, given earlier work showing that Republican and Democratic judicial appointees are constrained differently by statutory language in criminal 
case and employment cases. These findings underscore the importance of understanding the specific psychological mechanisms at work when we talk about ideology's role in judging, rather than relying upon "black box" accounts of judicial decision making. ${ }^{\text {xix }}$

Certainly, there are some limitations to this study that bear mentioning. Using the number of legal issues in the opinion without also having access to the accompanying briefs means that we are unable to observe issue suppression and other informal mechanisms that panels use to reach consensus when a case presents many elements. Indeed, some level of issue suppression is routine for judges, who regularly condense lengthy legal briefs with long lists of issues into relatively pithy opinions (Haire and Moyer 2008). Unfortunately, most circuits do not make their briefs electronically available, and even in those circuits that do, access to briefs is gained only through a fee-based service called PACER. Future research should explore the role that these briefs play in judges' decision making in the federal appellate courts. Additionally, research should examine other possible operationalizations of a "legal issue": for example, to test whether the effects differ across merits and procedural issues.

The lively debate over judicial decision making will no doubt continue for many years to come. Nevertheless, scholars should continue to explore the nuances of both legal and psychological influences in order to gain a fuller understanding of the process of decision making, not just outcomes. 


\section{Bibliography}

Altemeyer, R.A., 1998. "The Other 'Authoritarian Personality." Advances in Experimental Social Psychology, edited by M.P. Zanna, 47-92. New York: Academic Press.

Bailey, Michael A., Brian Kamoie, and Forrest Maltzman. 2005. "Signals from the Tenth Justice: the Political Role of the Solicitor General in Supreme Court Decision Making," American Journal of Political Science 49: 72-85.

Bartels, Brandon. 2009. "The Constraining Capacity of Legal Doctrine on the U.S. Supreme Court," American Political Science Review 103 (3): 474-95.

Baum, Lawrence. 1997. The Puzzle of Judicial Behavior. Ann Arbor: Univ. of Michigan Press.

Binder, Sarah, Eric Lawrence, and Forrest Maltzman. 1999. "Uncovering the Hidden Effect of Party," Journal of Politics 61 (3): 815-31.

Boucher, Robert L., and Jeffrey A. Segal. 1995. "Supreme Court Justices as Strategic Decision Makers: Aggressive Grants and Defensive Denials on the Vinson Court," Journal of Politics 57 (3): 824-37.

Bonneau, Chris W., and Melinda Gann Hall. 2009. In Defense of Judicial Elections. New York: Routledge.

Braman, Eileen. 2006. "Reasoning on the Threshold: Testing the Separability of Preferences in Legal Decision Making," Journal of Politics 68 (2): 308-21

Braman, Eileen, and Thomas E. Nelson. 2007. "Mechanism of Motivated Reasoning? Analogical Perception in Discrimination Disputes," American Journal of Political Science 51 (4): 940-56.

Brambor, Thomas, William Roberts Clark, and Matt Golder. 2006. "Understanding Interaction Models: Improving Empirical Analyses,” Political Analysis 14 (1): 63-82.

Caldeira, Gregory A., John R. Wright, and Christopher Zorn. 1999. "Sophisticated Voting and Gate-Keeping in the Supreme Court," Journal of Law, Economics, and Organization 15 (3): 549-72.

Cohen, Jonathan Matthew. 2002. Inside Appellate Courts: The Impact of Court Organization on Judicial Decision Making in the United States Courts of Appeals. Ann Arbor: Univ. of Michigan Press.

Cook, Beverly B. 1977. "Public Opinion and Federal Judicial Policy," American Journal of Political Science 21: 567-600. 
Converse, Philip. 1964. “The Nature of Belief Systems in Mass Publics.” In Ideology and Discontent, edited by David E. Apter, 206-261. New York: Free Press.

Cox, Gary W., and Matthew McCubbins. 1993. Legislative Leviathan: Party Government in the House. Univ. of California Press.

Cross, Frank B. 1997. "Political Science and the New Legal Realism: A Case of Unfortunate Interdisciplinary Ignorance," Northwestern University Law Review 92: 251-326.

Epstein, Lee, Andrew Martin, Jeffrey Segal, and Chad Westerland. 2007. "The Judicial Common Space," Journal of Law, Economics, and Organization 23 (2): 303-25.

Galanter, Marc. 1974. "Why the 'Haves' Come out Ahead: Speculations on the Limits of Legal Change," Law and Society Review 9: 95-160.

George, Tracy E., and Lee Epstein. 1992. "On the Nature of Supreme Court Decision Making." American Political Science Review 86: 323-37.

Giles, Michael W., Virginia A. Hettinger, and Todd Peppers. 2001. "Picking Federal Judges: A Note on Policy and Partisan Selection Agendas," Political Research Quarterly 54: 62341.

Gillman, Howard. 2001. "What's Law Got to Do with It? Judicial Behaviorialists Test the 'Legal Model' of Judicial Decision Making," Law and Social Inquiry 26 (2): 465-504.

Greenberg, J., and E. Jonas. 2003. "Psychological Motives and Political Orientation-the Left, the Right, and the Rigid: Comment on Jost et al. (2003)," Psychological Bulletin 129: 376-82.

Gruenfeld, Deborah H. 1995. "Status, Ideology, and Integrative Complexity on the U.S. Supreme Court: Rethinking the Politics of Political Decision Making," Journal of Personality and Social Psychology 68 (1): 5-20.

Guthrie, Chris, Jeffrey L. Rachlinski, and Andrew J. Wistrich. 2001. "Inside the Judicial Mind," Cornell Law Review 86 (4): 777-830.

Haire, Susan, and Laura Moyer. 2008. "Advocacy Through Briefs in the U.S. Courts of Appeals," Southern Illinois University Law Journal 32: 593-609.

Hettinger, Virginia A., Stefanie A. Lindquist, and Wendy L. Martinek. 2006. Judging on a Collegial Court: Influences on Federal Appellate Decision Making. Charlottesville: Univ. of Virginia Press.

Johnson, Charles. 1987. "Law, Politics, and Judicial Decision Making: Lower Federal Court Uses of Supreme Court Decisions," Law \& Society Review 21 (2): 325-40 
Jost, John T., Jack Glaser, Arie W. Kruglanski, and Frank J. Sulloway. 2003a. "Political Conservatism as Motivated Social Cognition," Psychological Bulletin 129: 339-75.

-- 2003b. "Exceptions that Prove the Rule_-Using a Theory of Motivated Social Cognition to Account for Ideological Incongruities and Political Anomalies: Reply to Greenberg and Jonas (2003)," Psychological Bulletin 129: 383-93.

The Judicial Research Initiative (JuRI) at the University of South Carolina. N.d. http://www.cas.sc.edu/poli/juri/appct.htm (accessed July 7, 2011).

Kaheny, Erin, Sara Benesh, and Susan B. Haire. 2008. "Change over Tenure: Voting, Variance, and Decision Making on the U.S. Courts of Appeals," American Journal of Political Science 52 (3): 490-503.

Karau, S.J., and J.R. Kelly. 1992. "The Effects of Time Scarcity and Time Abundance on Group Performance Quality and Interaction Process.” Journal of Experimental Social Psychological 28 (6): 542-71.

Kastellac, Jonathan P. 2001. "Panel Composition and Judicial Compliance on the U.S. Courts of Appeals," Journal of Law, Economics, and Organization 23 (2): 421-41.

Kingdon, John W. 1973. Congressmen's Voting Decisions. New York: Harper \& Row.

Klein, David E. 2002. Making Law on the U.S. Courts of Appeals. Cambridge: Cambridge Univ. Press.

Krehbiel, Keith. 1993. “Where's the Party?” British Journal of Political Science 23 (2): 235-66.

---. 1998. Pivotal Politics. Chicago: Univ. of Chicago Press.

Kritzer, Herbert M., and Mark J. Richards. 2003. "Jurisprudential Regimes and Supreme Court Decisionmaking: The Lemon Regime and Establishment Clause Cases," Law and Society Review 37: 827-40.

Kuersten, Ashlyn, and Susan B. Haire. 2006. Update to Multi-User Database on the United States Courts of Appeals, 1997-2002. Ann Arbor, MI: Inter-University Consortium for Political and Social Research.

Lindquist, Stefanie A. 2007. "Bureaucratization and Balkanization," University of Richmond Law Review 41 (3): 659-706.

Lindquist, Stefanie, Wendy Martinek, and Virginia Hettinger. 2007. "Splitting the Difference: Modeling Appellate Court Decisions with Mixed Outcomes." Law and Society Review 41 (2): 429-26. 
Lupia, Arthur. 2002. "Who Can Persuade Whom?: Implications from the Nexus of Psychology and Rational Choice Theory." In Thinking About Political Psychology, edited by James H. Kukliski, 51-88. New York: Cambridge Univ. Press.

McKenna, Judith A., Laural L. Hooper, and Mary Clark. 2000. "Case Management Procedures in the Federal Courts of Appeals." White paper produced by the Federal Judicial Center.

Norton, Edward C., Hua Wang, and Chunrong Ai. 2004. "Computing Interaction Effects and Standard Errors in Logit and Probit Models." The Stata Journal 4: 154-67.

Poole, Keith T., and Howard Rosenthal. 1991. "Patterns of Congressional Voting," American Journal of Political Science 35 (1): 228-78.

Posner, Richard. 1996. The Federal Courts: Challenge and Reform. Cambridge, MA: Harvard Univ. Press.

Pritchett, C. Herman. 1948. The Roosevelt Court: A Study in Judicial Politics and Values, 19371947. New York: Macmillan.

Randazzo, Kirk A., Richard W. Waterman, and Jeffrey A. Fine. 2006. "Checking the Federal Courts: The Impact of Congressional Statutes on Judicial Behavior," Journal of Politics 68: $1006-17$.

Ray, J.J. 1973. "Conservatism, Authoritarianism, and Related Variables: A Review and Empirical Study.” In The Psychology of Conservatism, edited by G.D. Wilson, 17-35. New York: Academic Press.

Richards, Mark J., and Herbert M. Kritzer. 2002. "Jurisprudential Regimes in Supreme Court Decision Making," The American Political Science Review 96: 305-20.

Robel, Lauren. 1990. “Caseload and Judging: Judicial Adaptations to Caseload,” Brigham Young University Law Review 3: 3-65.

Rohde, David, and Harold J. Spaeth. 1976. Supreme Court Decision-Making. San Francisco: WH Freeman.

Rokeach, M. 1960. The Open and Closed Mind. New York: Basic Books.

Rowland, C.K., and Robert A. Carp. 1996. Politics and Judgment in Federal District Courts. Lawrence, KS: Univ. Press of Kansas.

Schauer, Frederick. 2007. "Is there a Psychology of Judging?" Univ. of Pennsylvania Law Review 155: 165-202 
Schubert, Glendon. 1965. The Judicial Mind: The Attitudes and Ideologies of Supreme Court Justices, 1946-1963. Evanston: Northwestern Univ. Press.

Segal, Jeffrey A. 1984. "Predicting Supreme Court Cases Probabilistically: The Search and Seizure Cases, 1962-1981,” American Political Science Review: 78: 891-900.

Segal, Jeffrey A., Donald R. Songer, and Charles M. Cameron. 1995. "Decision Making on the U.S. Courts of Appeals." In Contemplating Courts, edited by Lee Epstein, 227-245. Washington, D.C.: Congressional Quarterly.

Segal, Jeffrey A., and Harold J. Spaeth. 1993. The Supreme Court and the Attitudinal Model. New York: Cambridge Univ. Press.

---. 2002. The Supreme Court and the Attitudinal Model Revisited. New York: Cambridge Univ. Press.

Shils, E.A. 1954. "Authoritarianism: 'Right' and 'Left."' Studies on the Scope and Method of the 'Authoritarian Personality', edited by R. Christie and M. Jahoda, 24-49. Glencoe, IL: Free Press.

Sidanius, Jim. 1984. "Political Interest, Political Information Search, and Ideological Homogeneity as a Function of Socio-Political Ideology: A Tale of Three Theories," Human Relations 37: 811-28.

Smith, Rogers M. 1994. "Remarks, Symposium on Supreme Court and the Attitudinal Model," Law and Courts: Newsletter of the Law and Courts Section of the American Political Science Association 4: 8-9.

Spaeth, Harold J. 1972. An Introduction to Supreme Court Decision Making, Revised Edition. New York: Chandler Publishing.

Spaeth, Harold J., and David J. Peterson. 1971. "The Analysis and Interpretation of Dimensionality: The Case of Civil Liberties Decision Making," Midwest Journal of Political Science 15 (3): 415-41.

Spellman, Barbara A. 2007. "On the Supposed Expertise of Judges in Evaluating Evidence," Univ. of Pennsylvania Law Review PENNumbra 156: 1-9. Available at: http://www.pennumbra.com/issues/articles/155-1/Spellman.pdf.

Songer, Donald. 1997. The United States Courts of Appeals Database. Ann Arbor, MI: InterUniversity Consortium for Political and Social Research. 
Songer, Donald, and Susan B. Haire. 1992. "Integrating Alternative Approaches to the Study of Judicial Voting: Obscenity Cases in the U.S. Courts of Appeals," American Journal of Political Science 36 (4): 963-82.

Songer, Donald R., and Reginald Sheehan. 1992. "Who Wins on Appeal? Upperdogs and Underdogs in the United States Courts of Appeals," American Journal of Political Science 36: 233-58.

Songer, Donald R., Reginald Sheehan, and Susan Brodie Haire. 1999. "Do the 'Haves' Come out ahead over Time? Applying Galanter's Framework to Decisions of the U.S. Courts of Appeals, 1925-1998," Law and Society Review 33: 811-32.

Tetlock, Philip E. 1983. "Cognitive Style and Political Ideology,” Journal of Personality and Social Psychology 45: 118-126.

Tetlock, Philip E., J. Bernzweig, and J. L. Gallant. 1985. "Supreme Court Decision Making: Cognitive Style as a Predictor of Ideological Consistency of Voting," Journal of Personality and Social Psychology 48 (5): 1227-39.

Tiller, Emerson H., and Frank Cross 1999. "A Modest Proposal for Improving American Justice,” Columbia Law Review 99 (1): 215-34.

Wasby, Stephen. 2008. "Clerking for an Appellate Judge: A Close Look," Seton Hall Circuit Review 5 (1): 19-97.

Zorn, Christopher J. W. 2001. "Generalized Estimating Equation Models for Correlated Data: A Review with Applications,” American Journal of Political Science 45 (2): 47090.

Zorn, Christopher J. W., and Jennifer Barnes Bowie. 2010. "Ideological Influences on Decision Making in the Federal Judicial Hierarchy: An Empirical Assessment," Journal of Politics 72 (4): 1212-21. 
Table 1: Likelihood of a Sincere Vote

U.S. Courts of Appeals (1982-2002)

\begin{tabular}{|c|c|c|c|}
\hline & $\begin{array}{c}\text { Model 1 } \\
\text { Coefficient } \\
\text { (Robust SE) }\end{array}$ & $\begin{array}{c}\underline{\text { Model 2 }} \\
\text { Coefficient } \\
\text { (Robust SE) }\end{array}$ & $\begin{array}{c}\underline{\text { Model 3 }} \\
\text { Coefficient } \\
\text { (Robust SE) }\end{array}$ \\
\hline \multicolumn{4}{|c|}{ Ideology and complexity variables } \\
\hline Legal complexity & $\begin{array}{l}.017 \\
(.077)\end{array}$ & $\begin{array}{l}.014 \\
(.077)\end{array}$ & $\begin{array}{l}-.002 \\
(.091)\end{array}$ \\
\hline Ideology & $\begin{array}{l}.956 * * \\
(.085)\end{array}$ & $\begin{array}{l}1.02 * * \\
(.159)\end{array}$ & $\begin{array}{l}.955^{* *} \\
(.085)\end{array}$ \\
\hline Extreme ideology & $\begin{array}{c}-.445^{* *} \\
(.074)\end{array}$ & $\begin{array}{c}-.444 * * \\
(.074)\end{array}$ & $\begin{array}{c}-.494 * * \\
(.139)\end{array}$ \\
\hline $\begin{array}{l}\text { Ideology*legal } \\
\text { complexity }\end{array}$ & -- & $\begin{array}{l}-.030 \\
(.062)\end{array}$ & -- \\
\hline $\begin{array}{l}\text { Extreme*legal } \\
\text { complexity }\end{array}$ & -- & -- & $\begin{array}{l}.024 * * \\
(.056)\end{array}$ \\
\hline Control variables & & & \\
\hline Non-unanimous & $\begin{array}{l}.324 * \\
(.132)\end{array}$ & $\begin{array}{l}.323^{*} \\
(.132)\end{array}$ & $\begin{array}{l}.325^{*} \\
(.132)\end{array}$ \\
\hline $\begin{array}{l}\text { Majority party in } \\
\text { circuit }\end{array}$ & $\begin{array}{l}.306 * * \\
(.036)\end{array}$ & $\begin{array}{l}.306 * * \\
(.036)\end{array}$ & $\begin{array}{l}.306 * * \\
(.036)\end{array}$ \\
\hline Cross appeal & $\begin{array}{l}-.055 \\
(.138)\end{array}$ & $\begin{array}{l}-.054 \\
(.138)\end{array}$ & $\begin{array}{l}-.055 \\
(.138)\end{array}$ \\
\hline U.S. government & $\begin{array}{l}.995 * * \\
(.056)\end{array}$ & $\begin{array}{l}.996 * * \\
(.057)\end{array}$ & $\begin{array}{l}.995 * * \\
(.056)\end{array}$ \\
\hline Lower court decision & $\begin{array}{l}2.97 * * \\
(.088)\end{array}$ & $\begin{array}{l}2.97 * * \\
(.088)\end{array}$ & $\begin{array}{l}2.97 * * \\
(.088)\end{array}$ \\
\hline $\begin{array}{l}\text { Ideo. distance from } \\
\text { panel }\end{array}$ & $\begin{array}{c}.050 \\
3(.134)\end{array}$ & $\begin{array}{c}.051 \\
(.134)\end{array}$ & $\begin{array}{c}.049 \\
(.134)\end{array}$ \\
\hline Constant & $\begin{array}{c}-.542 * * \\
(.116) \\
\end{array}$ & $\begin{array}{c}-.538 * * \\
(.116)\end{array}$ & $\begin{array}{c}-.515 * * \\
(.135)\end{array}$ \\
\hline$N$ & 11392 & 11392 & 11392 \\
\hline Prob $>$ chi 2 & $\mathrm{p}<.001$ & $\mathrm{p}<.001$ & $\mathrm{p}<.001$ \\
\hline Pseudo $\mathrm{R}^{2}$ & .4297 & .4297 & .4297 \\
\hline
\end{tabular}

Notes: ${ }^{* *} \mathrm{p}<.01, * \mathrm{p}<.05$, two-tailed tests. 


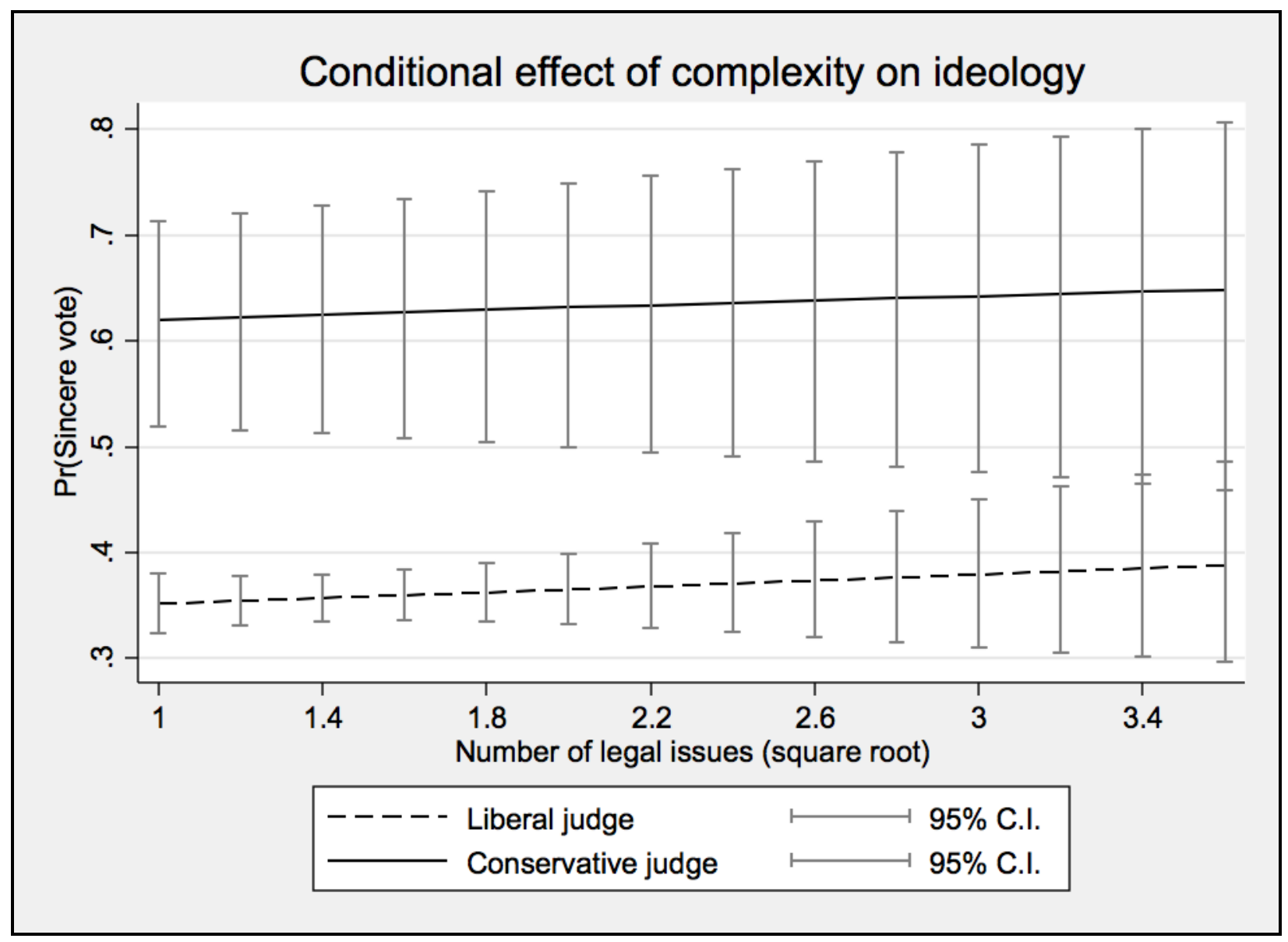

Figure 1. Interaction of Judge Ideology and Legal Complexity.

Note: Ideology ranges -.4 to .4 (the interquartile range), and the number of legal issues runs from its minimum to maximum value. All continuous variables set at their median values. Dummy variables set at moderate judge, in the majority of the circuit, lower court decision not consistent with preferences, no U.S. government participation, and no dissent). 


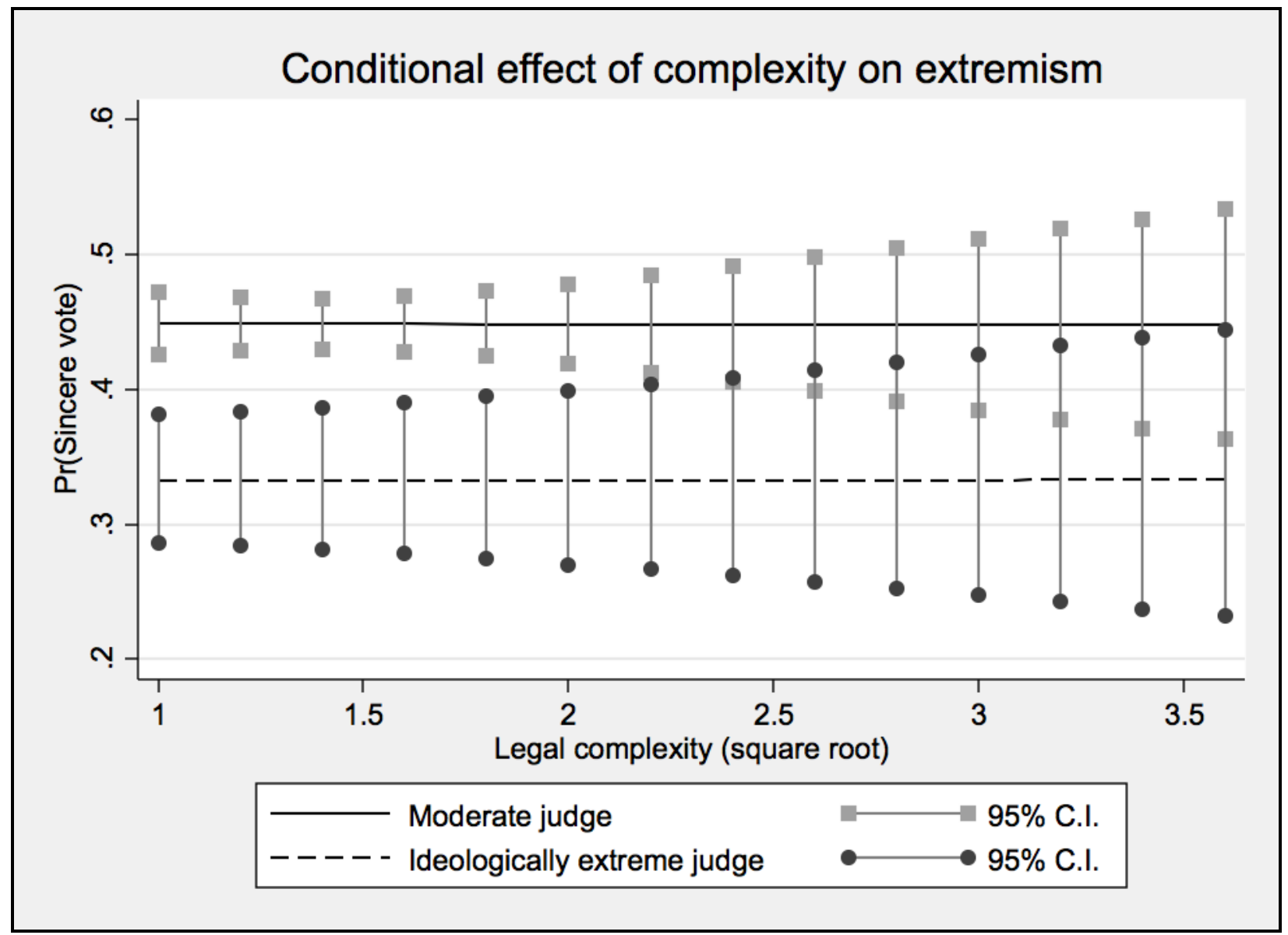

Figure 2. Interaction of Ideological Extremity and Legal Complexity.

Note: All continuous variables set at their median values. Dummy variables set at moderate judge, in the majority of the circuit, lower court decision not consistent with preferences, no U.S. government participation, and no dissent. Where the confidence intervals overlap, the difference in the probability between a moderate and an ideologically extreme judge are not statistically different from one another. 
Table 2: Likelihood of a Sincere Vote

Subsample: Civil and Criminal Cases

\begin{tabular}{|c|c|c|c|c|}
\hline & $\begin{array}{c}\frac{\text { Model 4a: }}{\text { Civil Cases }} \\
\begin{array}{c}\text { Coefficient } \\
\text { (RSE) }\end{array}\end{array}$ & $\begin{array}{l}\frac{\text { Model 4b: }}{\text { Civil Cases }} \\
\text { Coefficient } \\
\text { (RSE) }\end{array}$ & $\begin{array}{l}\frac{\text { Model 5a: }}{\text { Criminal }} \\
\text { Cases } \\
\text { Coefficient } \\
\text { (RSE) }\end{array}$ & $\begin{array}{c}\frac{\text { Model 5b: }}{\text { Criminal }} \\
\text { Cases } \\
\text { Coefficient } \\
\text { (RSE) }\end{array}$ \\
\hline \multicolumn{5}{|c|}{ Ideology and complexity variables } \\
\hline $\begin{array}{l}\text { Legal } \\
\text { complexity }\end{array}$ & $\begin{array}{l}.106 \\
(.090)\end{array}$ & $\begin{array}{l}.065 \\
(.108)\end{array}$ & $\begin{array}{l}.186 \\
.(213)\end{array}$ & $\begin{array}{l}-.047 \\
(.189)\end{array}$ \\
\hline Ideology & $\begin{array}{l}.465^{* *} \\
(.180)\end{array}$ & $\begin{array}{l}.333 * * \\
(.099)\end{array}$ & $\begin{array}{l}2.55 \\
(.457)\end{array}$ & $\begin{array}{l}3.55^{* *} \\
(.251)\end{array}$ \\
\hline $\begin{array}{l}\text { Extreme } \\
\text { ideology }\end{array}$ & $\begin{array}{l}-.471^{* *} \\
(.080)\end{array}$ & $\begin{array}{l}-.581^{* *} \\
(.157)\end{array}$ & $\begin{array}{l}.127 \\
(.222)\end{array}$ & $\begin{array}{l}.128 \\
(.374)\end{array}$ \\
\hline $\begin{array}{l}\text { Ideology*legal } \\
\text { complexity }\end{array}$ & $\begin{array}{l}-.060 \\
(.069)\end{array}$ & -- & $\begin{array}{l}.541^{*} \\
(.212)\end{array}$ & -- \\
\hline Non-unanimous & $\begin{array}{l}.270^{*} \\
(.139)\end{array}$ & $\begin{array}{l}.272 * \\
(.139)\end{array}$ & $\begin{array}{c}.644 \\
. .434)\end{array}$ & $\begin{array}{c}.622 \\
(.421)\end{array}$ \\
\hline $\begin{array}{l}\text { Member of } \\
\text { majority party in } \\
\text { circuit }\end{array}$ & $\begin{array}{l}.264 * * * \\
(.042)\end{array}$ & $\begin{array}{l}.263 * * \\
(.042)\end{array}$ & $\begin{array}{l}.466 * * \\
(.073)\end{array}$ & $\begin{array}{l}.452 * * * \\
(.072)\end{array}$ \\
\hline Cross appeal & $\begin{array}{l}-.140 \\
(.135)\end{array}$ & $\begin{array}{l}-.142 \\
(.135)\end{array}$ & $\begin{array}{l}1.10 \\
(.583)\end{array}$ & $\begin{array}{c}1.11 \\
(.582)\end{array}$ \\
\hline U.S. government & $\begin{array}{l}.826 * * \\
(.079)\end{array}$ & $\begin{array}{l}.825 * * \\
(.079)\end{array}$ & $\begin{array}{l}.720 * * \\
(.095)\end{array}$ & $\begin{array}{l}.742 * * \\
(.093)\end{array}$ \\
\hline $\begin{array}{l}\text { Lower court } \\
\text { decision }\end{array}$ & $\begin{array}{l}2.96 * * \\
(.099)\end{array}$ & $\begin{array}{l}2.97 * * \\
(.099)\end{array}$ & $\begin{array}{l}2.88 * * \\
(.220)\end{array}$ & $\begin{array}{l}2.89 * * \\
(.221)\end{array}$ \\
\hline $\begin{array}{l}\text { Ideo. distance } \\
\text { from panel }\end{array}$ & $\begin{array}{l}.146 \\
(.149)\end{array}$ & $\begin{array}{l}.142 \\
(.149)\end{array}$ & $\begin{array}{l}-.704 * \\
(.344)\end{array}$ & $\begin{array}{l}-.723^{*} \\
(.346)\end{array}$ \\
\hline Constant & $\begin{array}{c}-.671 * * \\
(.136)\end{array}$ & $\begin{array}{c}-.613 * * \\
(.160)\end{array}$ & $\begin{array}{l}-.541 \\
(.301)\end{array}$ & $\begin{array}{l}-.247 \\
(.282)\end{array}$ \\
\hline$N$ & 7281 & 7281 & 4111 & 4111 \\
\hline Prob > chi 2 & $\mathrm{p}<.001$ & $\mathrm{p}<.001$ & $\mathrm{p}<.001$ & $\mathrm{p}<.001$ \\
\hline Pseudo $\mathrm{R}^{2}$ & .3382 & .3382 & .6721 & .6703 \\
\hline
\end{tabular}

Notes: $* * \mathrm{p}<.01,{ }^{*} \mathrm{p}<.05$, two-tailed tests. All marginal effects and standard errors were calculated for all interaction terms, but the only statistically significant relationship was in Model 4b. This effect is graphed in Figure 3. (Other graphs are omitted because of space.) 


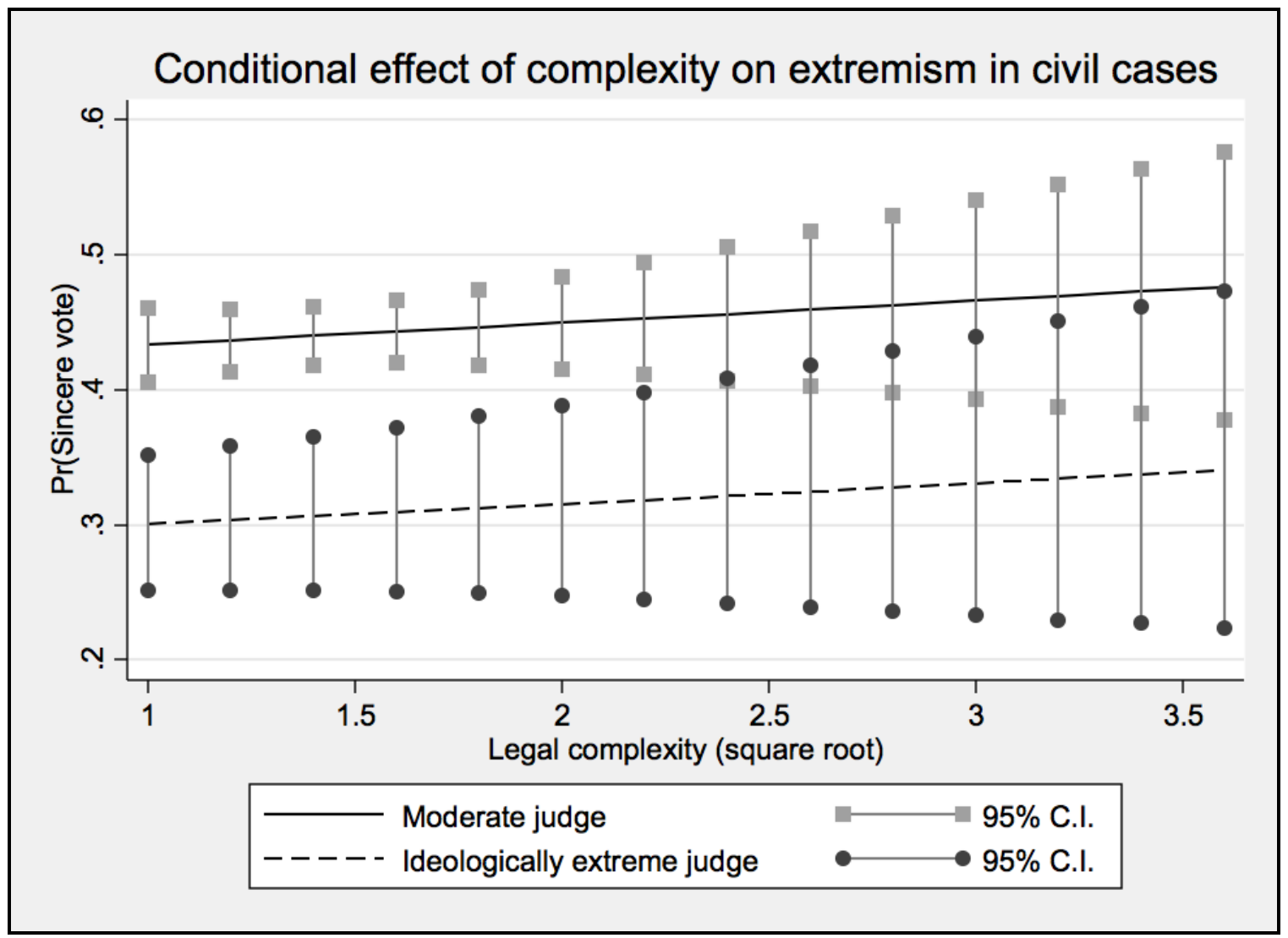

Figure 3. Interaction of Ideological Extremity and Legal Complexity.

Note: All continuous variables set at their median values. Dummy variables set at majority of the circuit, lower court decision not consistent with preferences, no U.S. government participation, and no dissent. Where the confidence intervals overlap, the difference in the probability between a moderate and an ideologically extreme judge are not statistically different from one another. 
Appendix A: Legal Issues Included in the Legal Complexity Variable

\begin{tabular}{|c|c|c|}
\hline Criminal & Civil & Civil con't \\
\hline $\begin{array}{l}\text { Prejudicial conduct by } \\
\text { prosecution } \\
\text { Insanity defense } \\
\text { Improper influence on jury } \\
\text { Jury instructions improper } \\
\text { Jury composition or selection } \\
\text { Death penalty } \\
\text { Sentence improperly imposed } \\
\text { Indictment defective } \\
\text { Confession improperly } \\
\text { admitted } \\
\text { Search and seizure } \\
\text { Admissibility of evidence } \\
\text { Challenges to plea bargain } \\
\text { Inadequate counsel } \\
\text { on other grounds } \\
\text { Right to counsel violated } \\
\text { undiciency of evidence for } \\
\text { Dismissal by lower court } \\
\text { Intid on procedural grounds } \\
\text { Intion }\end{array}$ & 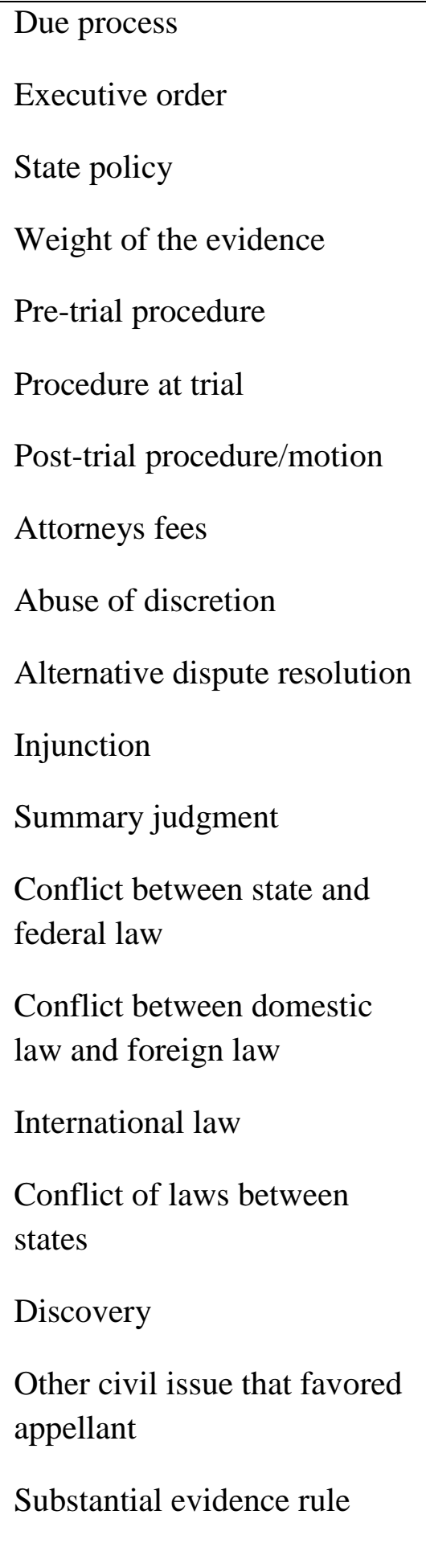 & $\begin{array}{l}\text { De novo } \\
\text { Clearly erroneous standard } \\
\text { Agency discretion } \\
\text { Decision subject to judicial } \\
\text { review } \\
\text { Agency used appropriate } \\
\text { standard or interpretation } \\
\text { Notice given } \\
\text { Administrative law judge } \\
\text { Agency acquisition of } \\
\text { information } \\
\text { Freedom of Information } \\
\text { Comment } \\
\text { Record adequately developed } \\
\text { Diversity of parties } \\
\text { Which law (in diversity } \\
\text { conflicts) }\end{array}$ \\
\hline
\end{tabular}




\section{Notes}

${ }^{\mathrm{i}}$ See Bonneau and Hall (2009) for a similar argument in the context of judicial elections.

ii This is also referred to in terms of "salience."

iii As a caveat, it should be noted that for judges in different institutional environments, some of the prerequisites for the behavior described by Segal and Spaeth are not satisfied. For instance, lower federal court judges and many state court judges have little or no say in choosing which cases they will hear. In addition, they may be motivated by ambition for higher judicial office, or constrained by the possibility of reversal by a higher court.

iv See Bartels (2009) for a newer strain of scholarship that acknowledges the role of both law and ideology in judicial decision making.

${ }^{\mathrm{v}}$ The literature on political attitudes and behavior has also recognized that, in some situations, ideology is malleable, and might be issue-specific. However, I follow Jost et al. (2003, 342 fn2) in assuming that we can distinguish between a stable core of beliefs that are associated with individual ideology (e.g., preferences about change, inequality, and order) and attitudes on specific issues (e.g., crime).

vi The motivated reasoning account suggests a biased decision process, by which decision makers are predisposed to find authorities consistent with their ideological preferences more convincing than authorities that conflict with those preferences.

vii While the Supreme Court also operates by majority rule, substantially different norms exist in that institution about separate opinion writing. From 1950 to 1990, the U.S. Supreme Court maintained a dissent rate that was well above fifty percent (Haynie 1992), compared to a dissent rate of 7 percent on the Courts of Appeals during the same period (Songer, Sheehan, and Haire 2000). As a result of the prevalence of consensus, the median judge on a Courts of Appeals 
panel yields more of an influence over her colleagues, in terms of the ideological direction of the court's opinion, than the median justice on the Supreme Court.

viii Yearly terminations on the merits is a preferable measure to total filings, since the latter does not signify whether the court considered the arguments and resolved the case in that year.

${ }^{\text {ix }}$ Interview with the author (December 2008).

${ }^{\mathrm{x}}$ One limitation of using the headnotes variable is that it is truncated by the number of fields coded in the Songer database (the variable ranges from 0 to 7 ).

xi The substantive findings are robust to alternative specifications of the dependent variable in which a sincere vote is coded as a dichotomy based on the judge ideology scores, rather than party of appointing president. (See Appendix C.)

xii I also ran the models using a cross-sectional time-series analysis (Zorn 2001). As the results of both methods were substantively equivalent, I report the logit results for ease of interpretation. Another alternative specification would be to include fixed effects to control for circuit-specific tendencies. However, introducing these controls produces unacceptably high levels of collinearity with the Majority variable (>.90), so I opted not to include them. xiii When the observations are separated by party of appointing president, 24 percent of all Democratic judge-votes were classified as coming from "extreme" judges, while 40 percent of all Republican judge-votes had this designation.

${ }^{\text {xiv }}$ This measure does not tap into the relative weight of each issue, or into the court's ruling on each issue. In addition, the dependent variable in the analysis is coded relative to the outcome of the entire case, so it is possible that in case with multiple issues, some, but not necessarily all, of these issues will have been decided consistent with the outcome of the case. 
${ }^{\mathrm{xv}}$ The legal concepts were coded as part of the Multi-User database to reflect whether the court addressed the issue in a way that favored the appellant, the appellee, both (mixed decisions), or if the court did not address the issue at all. My coding scheme simply notes whether the court addressed the issue at all, regardless of which side prevailed and sums the number of issues addressed by the court in its majority opinion.

${ }^{x v i}$ When the value for Lower Court is set at 1, the probability of sincere voting for liberal and conservative judges increase dramatically, reflecting the powerful effect of this control variable. Liberal judges' probabilities range from .91 to .92 (compared to .35 to .39 when Lower Court is equal to 0), while a conservative judge goes from .98 to .99 (compared to .62 - .65). After Legal Complexity exceeds 3 , the differences between liberal and conservative judges are no longer statistically different from one another.

xvii Supplemental analyses were also conducted using only civil rights and liberties cases, since ideology may be more salient in such cases. However, the substantive findings remain largely the same. The only difference is that the Extreme weakens in statistical significance from $\mathrm{p}<.001$ to $\mathrm{p}<.10$

xviii When the models are estimated without the interaction terms, Legal Complexity fails to reach conventional levels of significance, and the results largely mirror the findings in Table 1.

${ }^{\text {xix }}$ This is not to say that liberal or conservative judges consciously rely on shortcuts in the place of legal arguments, or that they are simply trying to decide cases quickly without regard to the quality of their work; indeed, there is ample evidence that judges value and strive to produce high quality legal work every time a case comes before them. 


\section{AUTHOR BIO}

Laura Moyer is an assistant professor of political science at Louisiana State University. Her research examines influences on judicial decision making in the U.S. Courts of Appeals, with an emphasis on judicial characteristics such as race and gender, institutional context, and the law. 